\title{
Diagrammatic scales for the estimation of black node disease severity in common bean
}

\author{
Yuranis Miranda Montero ${ }^{1}$ (i) Linda Rincón Rivera ${ }^{2}$ (i) Luz Nayibe Garzón Gutiérrez ${ }^{*}$ (i) \\ ${ }^{1}$ Faculty of Science, Biology School, Universidad Industrial de Santander (UIS), 680002, Bucaramanga, Santander, Colombia. E-mail: \\ lngarzon@uis.edu.co. "Corresponding author. \\ ${ }^{2}$ Agricultural Sciences Faculty, Universidad Nacional de Colombia Bogotá, Cundinamarca, Colombia.
}

ABSTRACT: The objective of this study was to design two diagrammatic scales for the evaluation of black node disease (Stagonosporopsis hortensis and Boeremia spp.) in common bean (Phaseolus vulgaris L.). The developed scales corresponded to logarithmic intervals (SADL) of seven levels and equal intervals (SADE) of nine levels. These scales were compared to the scale developed by the International Center for Tropical Agriculture (CIAT), which corresponds to a descriptive scale (NoSAD). In the scale validation the accuracy, precision, and concordance of repeatability were determined using Lin's concordance correlation coefficient, whereas inter-rater reproducibility was determined by the overall concordance correlation coefficient (OCCC). It was observed that with the use of the proposed scales, reproducibility and repeatability were significantly improved for inexperienced raters, and reproducibility was improved in the case of experienced raters. Thus, the designed standard area diagrams with equal and logarithmic intervals are a useful tool for estimating severity under field and experimental conditions as part of the study of this patho-system.

Key words: Boeremia, standard area diagrams, Phaseolus vulgaris, phytopathometry.

Escalas diagramáticas para a estimativa da gravidade da doença do nó negro no feijão comum

RESUMO: O objetivo deste estudo foi delinear duas escalas diagramáticas para avaliação da doença do nó preto (Stagonosporopsis hortensis e Boeremia spp.) em feijoeiro (Phaseolus vulgaris L.). As escalas desenvolvidas corresponderam a intervalos logaritmicos (SADL) de sete niveis e intervalos iguais (SADE) de nove niveis. Essas escalas foram comparadas com a escala desenvolvida pelo Centro Internacional de Agricultura Tropical (CIAT), que corresponde a uma escala descritiva (NoSAD). Na validação da escala, a exatidão, precisão e concordância da repetibilidade foram determinadas usando o coeficiente de correlação de concordância de Lin, enquanto a reprodutibilidade entre avaliadores foi determinada pelo coeficiente de correlação de concordância geral (OCCC). Observou-se que, com o uso das escalas propostas, a reprodutibilidade e a repetibilidade foram significativamente melhoradas para os avaliadores inexperientes, e a reprodutibilidade foi melhorada no caso dos avaliadores experientes. Assim, as escalas diagramáticas projetadas são uma ferramenta útil para estimar a severidade em condições experimentais e de campo como parte do estudo desse sistema patológico.

Palavras-chave: Boeremia, diagramas de área padrão, Phaseolus vulgaris, fitopatometria.

In common bean (Phaseolus vulgaris) the black node disease is caused by the species Boeremia diversispora (Bubák), B. exigua (Desm.), B. noackiana (Allesch.), and Stagonosporopsis hortensis (Sacc. \& Malbr.) (SCHMIT \& BAUDOIN 1992; AVESKAMP et al. 2010). This disease causes over $70 \%$ yield losses in some regions (CIAT, 1983). The lesions appear mainly on plant leaves and pods and turn brown when tissue necrosis occurs.

The area affected by the symptoms is evaluated to determine severity; visual evaluation by qualitative or quantitative severity scales can be used for this task (BOCK et al. 2010; NUTTER et al. 2006). In the qualitative scales there are descriptive scales (classes based on the symptoms description) and ordinal scales (levels that describe the symptoms that represent an increase in disease severity). Regarding quantitative scales, they are those that assign percentage values to the disease severity, either of intervals (e.g., $5 \%$ to $10 \%$ ) or unique values (e.g., $5 \%$ ). In the case of interval scales, they can be logarithmic as proposed by HORSFALL \& BARRATT (1945) or of equal amplitude as proposed by NITA et al. (2003). Any scale can use diagrams or photographs to represent the disease, these kinds of scales are called diagrammatic scales or standard area diagrams (SAD) (DEL PONTE et al. 2017). 
Although, some scales to evaluated black node disease in common bean have been developed, these scales have not been validated (STONEHOUSE, 1994; CASTAÑO, 2002). The International Center for Tropical Agriculture developed an ordinal and descriptive scale, with nine severity levels (SCHOONHOVEN \& PASTOR-CORRALES, 1987), which is called NoSAD in the present study. Although, this scale does not have a description for even levels neither a standard area diagram, is currently widely being used in the evaluation of bean germplasm.

Thus, the objective of this study was to develop and evaluate two quantitative diagrammatic scales with photographic support from leaves of commercial crop plants. These scales were designed using both equal (SADE) and logarithmic (SADL) intervals. They were compared to the nondiagrammatic ordinal scale (NoSAD) that CIAT previously established in order to determine if there were significant differences in accuracy, precision, and reliability in the estimates obtained with the use of each scale.

Two hundred leaves of plants that showed different degrees of disease severity were collected in different commercial bean crops in Colombia. Each of these samples was photographed with a digital camera (Nikon D3400, 24.2 megapixels). Image analysis was performed individually using the ImageJ program (ImageJ, NIH, Bethesda, ML). The limits of the scales were established, considering into account the maximum disease severity reported in the plant material with the entire leaf area. The intervals of the scales were defined by two methodologies: logarithmically as established by HORSFALL \& BARRATT (1945) and with intervals of equal amplitude as proposed by NITA et al. (2003), maintaining the nine levels of the standard system for the evaluation of bean germplasm determined by SCHOONHOVEN \& PASTOR CORRALES (1987).

Scale validation was performed with five raters with experience and five raters without experience in disease evaluation, using the NoSAD scale and the SADL and SADE scales proposed in the present study. Forty randomly projected images covering different severity levels were evaluated. This exercise was performed three times to estimate its repeatability for each scale, with a minimum of seven days between each one.

Lin's concordance correlation coefficient (LCCC (pc)) was calculated to assess precision and accuracy. To establish if there were differences between the means of the LCCC statistics, a bootstrap of 10,000 repetitions was performed. The mean was calculated, and the equivalence test was performed, taking into account the $95 \%$ confidence interval (CI) from the difference between means. To evaluate the intra-rater reliability, Lin's coefficient of the estimates obtained by each rater was calculated. The mean reliability was determined, and it was established if there were significant differences between experienced and inexperienced raters when comparing the first and second, and the second and third repetitions. Regarding reproducibility of the estimates between raters, the overall concordance correlation coefficient (OCCC) was calculated for each repetition (CORREIA et al. 2017). The same procedure described for LCCC statistics was performed to determine if there were significant differences.

The lower and upper limits were established with values of $0.3 \%$ and $54 \%$, respectively. GODOY et al. (2006) define the upper limit as the amount of disease in which leaf abscission occurs. In the reported bean scales, this value corresponds to $24 \%$ (GODOY et al. 1997) and 51\% of leaf area affected (DÍAZ et al. 2001). Although, the maximum value of actual severity was $54 \%$, it is possible to find higher values, however, their estimation is difficult since the detachment of one or two leaflets is frequent, and there is a presence of wrinkled or rolled leaves. Likewise, other pathogens can be reported in advanced stages of infection, so the actual estimation of leaf area affected by the causative agent of the black node disease is limited. Thus, the maximum severity value observed is consistent with that reported by DEL PONTE et al. (2017), who estimated that the maximum severity value was less than $60 \%$ in half of the scales when analyzing 105 SAD.

Thus, the values of the first seven categories proposed by HORSFALL \& BARRATT (1945), were used in the elaboration of the scale with standard area diagrams of logarithmic intervals (SADL), in which the maximum limit corresponded to values greater than $50 \%$ (scale not shown). In the case of the scale with standard area diagrams of equal intervals (SADE), nine categories were established with an interval size of seven, and thus the maximum limit was for severities higher than $49 \%$ (Figure 1).

Experienced raters did not show any significant differences in accuracy, with the use of the three scales, since the bias factor correction ( $C b$ ) values were close to 0.8 (Table 1). The opposite results were observed for inexperienced raters since significant differences were obtained when comparing the means of NoSAD to the ones of SADL and SADE. These results indicated that 


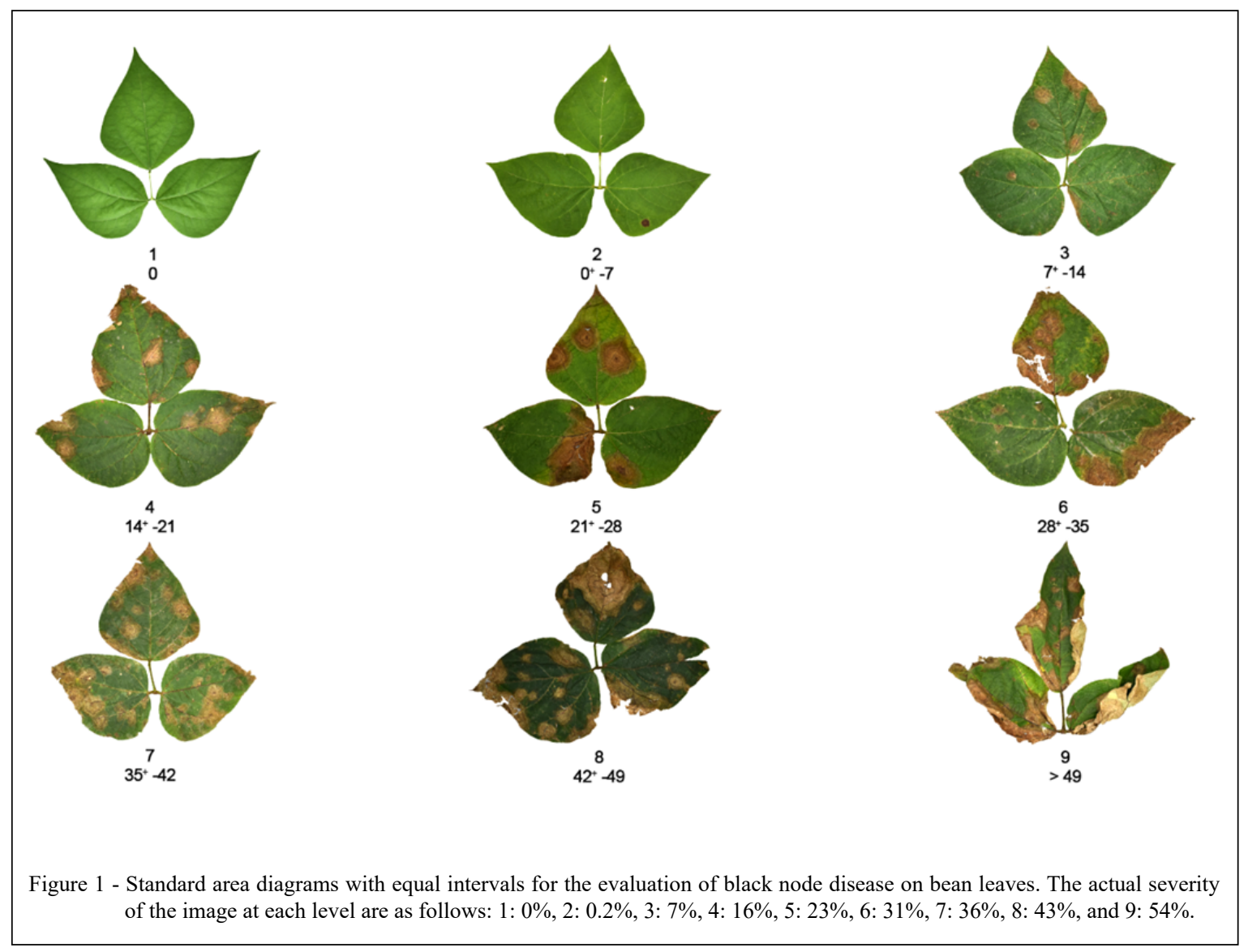

inexperienced raters assigned severity values closer to the actual value when they had a reference image. Regarding precision, there were no significant differences in the estimates when comparing the correlation coefficient $(r)$ of the three scales in the two groups of raters (Table 1).

For experienced raters to the location shift (u) parameter, significant differences were reported when comparing NoSAD (0.4158) and SADL (0.5161) scales to SADE (0.6622), which suggested that the overestimation increased with this scale. On the contrary, for inexperienced raters, NoSAD (0.8592) and SADL (0.4564) showed significant differences, but they were not observed when compared to SADE (0.6097). Thus, inexperienced raters overestimated the disease more with the use of NoSAD, followed by SADE (Table 1). These results would confirm what NUTTER et al. (2006) stated, who indicated that the scales based on Horsfall and Barrat were not necessarily invalid, but required further analyses to corroborate the severity estimated by raters when using intervals. In this sense, the validation of the scale is essential as it is a process that allows comparing the estimates of disease severity obtained by the use of the scale versus the actual value, establishing if its use improves accuracy, precision, and reliability.

When comparing the results of Lin's coefficient of experienced and inexperienced raters for the NoSAD scale, significant differences were reported between the means in four of the five statistics of this coefficient. Experienced raters using NoSAD had higher concordance values, which means greater accuracy and precision compared to inexperienced raters. However, the concordance of the estimates by inexperienced raters when using SADE and SADL did not show significant differences compared to the estimates of experienced raters. Based on these results, it can be considered that the use of diagrams improves estimates by inexperienced raters up to the point of performing similarly to an experienced rater, as observed in other studies (YADAV et al. 2012; GONZÁLEZ-DOMÍNGUEZ et al. 2014; LAGE et al. 2015). It should be noted that

Ciência Rural, v.51, n.3, 2021. 
Table 1 - Lin's concordance correlation coefficient (LCCC). Concordance of the estimates of black node disease severity on bean leaves carried out by experienced and inexperienced raters using the NoSAD, SADL, and SADE scales.

\begin{tabular}{|c|c|c|c|c|c|c|c|}
\hline \multirow[t]{2}{*}{ Rater } & \multirow{2}{*}{$\begin{array}{c}\text { LCC } \\
\text { statistics }\end{array}$} & \multicolumn{3}{|c|}{-------------------Means------------------ } & \multirow{2}{*}{$\begin{array}{c}\text { CI } 95 \% \text { NoSAD- }^{*} \\
\text { SADL }^{*}\end{array}$} & \multirow{2}{*}{$\begin{array}{c}\text { CI } 95 \% \text { NoSAD- } \\
\text { SADE }^{*}\end{array}$} & \multirow{2}{*}{$\begin{array}{c}\text { CI } 95 \% \\
\text { SADL-SADE }\end{array}$} \\
\hline & & No SAD & SADL & SADE & & & \\
\hline \multirow{5}{*}{ Experienced } & $\mathrm{v}$ & 1.226 & 1.3519 & 1.2448 & -0.33570 .0920 & -0.21000 .1832 & -0.041360 .2664 \\
\hline & $\mathrm{u}$ & 0.4158 & 0.5161 & 0.6622 & -0.34710 .1173 & $-0.4864-0.0362$ & $-0.2805-0.0081$ \\
\hline & $\mathrm{Cb}$ & 0.8370 & 0.8405 & 0.8004 & -0.08430 .0766 & -0.03950 .1098 & -0.03110 .1065 \\
\hline & $\mathrm{r}$ & 0.9325 & 0.9303 & 0.9321 & -0.01560 .0190 & -0.01840 .01915 & -0.01630 .0135 \\
\hline & $\mathrm{pc}$ & 0.7806 & 0.7816 & 0.7467 & -0.07530 .0730 & -0.03920 .1058 & -0.02880 .0956 \\
\hline \multirow{5}{*}{ Inexperienced } & $\mathrm{v}$ & 1.3966 & 1.2770 & 1.0721 & -0.08400 .3309 & 0.12950 .5320 & 0.09240 .3141 \\
\hline & $\mathrm{u}$ & 0.8592 & 0.4564 & 0.6097 & 0.07920 .7173 & -0.07920 .5692 & -0.35030 .0444 \\
\hline & $\mathrm{Cb}$ & 0.6866 & 0.8597 & 0.8214 & $-0.2872-0.0581$ & $-0.2539-0.0183$ & -0.03450 .1090 \\
\hline & $\mathrm{r}$ & 0.7885 & 0.8563 & 0.8517 & -0.15410 .0079 & -0.15540 .0189 & -0.05060 .0620 \\
\hline & $\mathrm{pc}$ & 0.5459 & 0.7390 & 0.7053 & $-0.3132-0.0689$ & $-0.2878-0.0257$ & -0.06090 .1275 \\
\hline
\end{tabular}

*95\% CI containing " 0 " indicates that there are no significant differences between the calculated means. Bold numbers represent significant differences. Scale shift $(v)$, Location shift $(u)$, Bias correction factor $(\mathrm{Cb})$, Correlation coefficient $(r)$, Concordance coefficient $(p c)$.

inexperienced raters did not receive any training to perform severity estimation.

Regarding inter-rater reproducibility, both experienced and inexperienced raters increased reliability with the use of SADE or SADL, which indicated that there is a more considerable agreement of the estimates performed between raters with the use of diagrammatic scales compared to the use of NoSAD (Table 2).

Thus, the scales proposed in this project, provided an advantage over evaluation with NoSAD scales for people who are not familiar with the disease. They also improved inter-rater reliability among experienced raters, which is essential in case of experiments that are carried out in different locations where several people are in charge of data collection. Additionally, it is necessary to introduce severity diagrams in the range from 0 to $7 \%$ since they support decision-making processes regarding the selection of materials for the study of disease resistance. Thus, it would be necessary to establish the thresholds for a bean plant that is resistant, intermediate resistant, and susceptible to the black node disease. However, based on the results obtained in the present study with the scales of diagrams, SADE is proposed as an alternative tool to the CIAT scale since it enables the obtaining of a disease estimate in a more exact and precise way. Furthermore, it maintains the nine standard levels that can be useful for people who are interested in bean cultivation and black node disease research.

Table 2 - Reproducibility by rater group in the three repetitions for the estimation of black node disease severity on bean leaves with the use of NoSAD, SADL, and SADE scales.

\begin{tabular}{|c|c|c|c|c|c|c|}
\hline \multirow[t]{2}{*}{ Rater } & \multicolumn{3}{|c|}{---------------------Means-------------------- } & \multirow{2}{*}{$\begin{array}{c}\text { CI 95\% } \\
\text { NoSAD-SADL }\end{array}$} & \multirow{2}{*}{$\begin{array}{c}\text { CI } 95 \% \text { NoSAD- } \\
\text { SADE }\end{array}$} & \multirow{2}{*}{$\begin{array}{c}\text { CI 95\% SADL- } \\
\text { SADE }\end{array}$} \\
\hline & NoSAD & SADL & SADE & & & \\
\hline Experienced & 0.74 & 0.84 & 0.85 & $-0.17-0.03$ & $-0.19-0.04$ & $\begin{array}{ll}-0.06 & 0.03\end{array}$ \\
\hline Inexperienced & 0.44 & 0.74 & 0.72 & -0.380 .22 & $-0.35-0.21$ & $\begin{array}{ll}-0.05 & 0.09\end{array}$ \\
\hline
\end{tabular}

"95\% CI containing " 0 " indicates that there are no significant differences between the calculated means. Bold numbers represent significant differences. 


\section{ACKNOWLEDGMENTS}

The authors would like to thank CIAT researchers and non-experts for their time in the validation of the scales, and Alberto Rojas Triviño and Gloria Mosquera for their valuable comments on the manuscript, and Ministry of Science, Technology and Innovation. Grant number 110271351710 046-2016 for financial support.

\section{DECLARATION OF CONFLICT OF INTERESTS}

The authors declare no conflict of interest. The founding sponsors had no role in the design of the study; in the collection, analyses, or interpretation of data; in the writing of the manuscript, and in the decision to publish the results.

\section{AUTHORS' CONTRIBUTIONS}

The authors contributed equally to the manuscript.

\section{REFERENCES}

AVESKAMP, M. M. et al. Highlights of the Didymellaceae: A polyphasic approach to characterise Phoma and related pleosporalean genera. Studies in Mycology, v.65, p.1-60, 2010. Available from: <http://www.ncbi.nlm.nih.gov/pmc/ articles/PMC2836210/>. Accessed: Jan. 12, 2017. doi: 10.3114/ sim.2010.65.01.

BOCK, C. H. et al. Plant disease severity estimated visually, by digital photography and image analysis, and by hyperspectral imaging. Critical Reviews in Plant Sciences, v.29, p.59-107, 2010. Available from: <http://www.tandfonline.com/doi/ abs/10.1080/07352681003617285>. Accessed: Jan. 17, 2017. doi: $10.1080 / 07352681003617285$

CASTAÑO, J. Monitoreo de epidemias: Enfermedad. In Principios básicos de fitoepidemiología, Manizales, Colombia: Universidad de Caldas, 2002 p. 121-147.

CIAT. Bean program annual report. Cali, Colombia.1983. 237 p.Available from: $<$ https://cgspace.cgiar.org/handle/10568/78956>. Accessed: Nov. 9, 2019.

CORREIA, K. C. et al. Development and evaluation of a standard area diagram set for the severity of phomopsis leaf blight on eggplant. European Journal of Plant Pathology, v.149, p.269-276, 2017. Available from: <http://link.springer.com/10.1007/s10658-0171184-y>. Accessed: Dec. 12, 2017. doi: 10.1007/s10658-017-1184-y.

DEL PONTE, E. M. et al. Standard area diagrams for aiding severity estimation: scientometrics, pathosystems, and methodological trends in the last 25 years. Phytopathology, v.107, p.1161-1174, 2017. Available from: < http://apsjournals.apsnet.org/doi/10.1094/ PHYTO-02-17-0069-FI>. Accessed: May, 24, 2018. doi: 10.1094/ PHYTO-02-17-0069-FI

DÍAZ, C. G. et al. Desenvolvimento e validação de uma escala diagramática para Xanthomonas axonopodia pv. phaseoli em feijoeiro. Summa Phytopathologica, v.27, p.35-39, 2001. Available from: <https://www.researchgate.net/ publication/292446234>. Accessed: Oct. 3, 2019.

GONZÁLEZ-DOMÍNGUEZ, E. et al. Development and validation of a standard area diagram set to aid assessment of severity of loquat scab on fruit. European Journal of Plant Pathology, v.139, p.413-422, 2014 Available from: <http://link.springer. com/10.1007/s10658-014-0400-2>. Accessed: Dec. 12, 2017. doi: 10.1007/s10658-014-0400-2.

GODOY, C. et al. Diagrammatic scales for bean diseases: development and validation. Journal of Plant Diseases and Protection, v.104, p.336-345, 1997. Available from: <https://bit. ly/2GQRnRH>. Accessed: May, 24, 2018.

GODOY, C. V. et al. Diagrammatic scale for assessment of soybean rust severity. Fitopatologia Brasileira, v.31, p.63-68, 2006. Available from: $<$ http://www.scielo.br/scielo.php?pid=S010041582006000100011\&script $=$ sci_arttext\&tlng $=$ pt $>$. Accessed: Jan. 22, 2017. doi: 10.1590/S0100-41582006000100011.

HORSFALL, J. G.; BARRATT, R. W. An improved grading system for measuring plant disease. Phytopathology, v.35, p.655, 1945.

LAGE, C. D. A. et al. Standard area diagrams for assessment of powdery mildew severity on tomato leaves and leaflets. Crop Protection, v.67, p.26-34, 2015. Available from: <http:// linkinghub.elsevier.com/retrieve/pii/S026121941400297X > . Accessed: Jan. 17, 2017. doi: 10.1016/j.cropro.2014.09.014.

NITA, M. et al. Reliability and accuracy of visual estimation of Phomopsis leaf blight of strawberry. Phytopathology, v.93, p.9951005, 2003. Available from: <http://apsjournals.apsnet.org/doi/ abs/10.1094/PHYTO.2003.93.8.995>. Accessed: Jan. 22, 2017. doi. 10.1094/PHYTO.2003.93.8.995.

NUTTER, F. W. et al. Disease assessment concepts and the advancements made in improving the accuracy and precision of plant disease data. European Journal of Plant Pathology, v.115, p.95-103, 2006. Available from: <http://link.springer. com/10.1007/s10658-005-1230-z>. Accessed: Mar. 30, 2017. doi: 10.1007/s10658-005-1230-z.

SCHMIT, V.; BAUDOIN, J. P. Screening for resistance to Ascochyta blight in populations of Phaseolus coccineus L. and $P$. polyanthus Greenman. Field Crops Research, v.30, p.155-165, 1992. Available from: <http://www.sciencedirect.com/science/ article/pii/037842909290064G>. Accessed: Mar. 17, 2017. doi: 10.1016/0378-4290(92)90064-G.

SCHOONHOVEN, A. V.; PASTOR-CORRALES, M. A. Standard system for the evaluation of bean germplasm. Centro Internacional de Agricultura Tropical. Cali, Colombia. 1987.

STONEHOUSE, J. Assessment of Andean bean diseases using visual keys. Plant Pathology, v.43, p.519-527, 1994Available from: $<$ http://onlinelibrary.wiley.com/doi/10.1111/j.1365-3059.1994. tb01586.x/full>. Accessed: Mar. 17, 2017.

YADAV, N. et al. Development and validation of standard area diagrams to aid assessment of pecan scab symptoms on fruit. Plant Pathology, v.62, p.325-335, 2012. Available from: <http:// bit.ly/3au5TOI>. Accessed: Oct. 3, 2019. doi: 10.1111/j.13653059.2012.02641.x 